\title{
THE
}

$1-16-2021$

\section{Overstraining Human Nature in the Nicomachean Ethics}

Douglass Reed

University of Rhode Island, douglassreed@uri.edu

Follow this and additional works at: https://digitalcommons.uri.edu/phl_facpubs

The University of Rhode Island Faculty have made this article openly available.

Please let us know how Open Access to this research benefits you.

This is a pre-publication author manuscript of the final, published article.

Terms of Use

This article is made available under the terms and conditions applicable towards Open Access

Policy Articles, as set forth in our Terms of Use.

\section{Citation/Publisher Attribution}

Reed, D. (2021). Overstraining Human Nature in the Nicomachean Ethics. Journal of the History of Philosophy 59(1), 45-67. http://doi.org/10.1353/hph.2021.0002 
** This is the manuscript version of the paper. Please cite the published version**

Copyright ( 2021 Journal of the History of Philosophy. This article first appeared in Journal of the History of Philosophy, Volume 59, Issue 1, January, 2021, pages 45-67. Published by Johns Hopkins University Press.

\section{Overstraining human nature in the Nicomachean Ethics Doug Reed}

Abstract: I investigate Aristotle's claim in Nicomachean Ethics 3.1 about situations that 'overstrain human nature'. By setting out and answering several interpretative questions about such situations, I offer a comprehensive interpretation of this passage. I argue that in (at least some of) these cases, the agent voluntarily does something wrong, even though there is a right action available. Furthermore, I argue that Aristotle would think it is possible for a rare agent to perform the right action in (at least some of) these cases, overcoming the limitations of human nature by identifying with the divine part of the soul.

Keywords: Aristotle, ethics, voluntary, human nature

In a tantalizingly brief passage in Nicomachean Ethics 3.1, Aristotle mentions situations that he

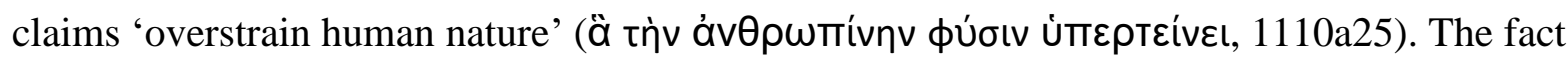
that he does not elaborate on what he has in mind is fair enough; his goal in the chapter is to offer an account of voluntariness and spelling out his thoughts about such situations would divert him from this task. But it is disappointing that by and large scholars have not been tempted to unpack this line, content instead to discuss it in passing. ${ }^{1}$ This neglect is not surprising given the difficulties commentators face in trying to make sense of Aristotle's view of the voluntary. Yet, as I will show, there are serious questions for how 'overstraining cases' stand with regard to Aristotle's analysis of the voluntary. Accordingly, our understanding of the view in NE 3.1 is incomplete without a comprehensive account of his view of overstraining cases.

\footnotetext{
${ }^{1}$ C.C.W. Taylor's commentary on NE $2-4$ is a valuable exception. See pages $134-139$.
} 
While the foregoing should provide sufficient motivation to examine this passage, there are further, and perhaps more significant reasons to do so. As I shall also show, this passage has implications for two fundamental issues in Aristotle's ethical theory in the $N E$ : the limits of ethics and the relationship between the political life and the contemplative life.

Regarding the first issue, I will argue that Aristotle thinks that there can be a morally right action even in situations that overstrain human nature. Hence, our human nature alone does not set the limits of ethics. Regarding the second, I will argue that the mention of human nature in this passage should bring to our minds Aristotle's contrast elsewhere in the $N E$ between our human nature and our divine nature. Recognizing this contrast opens up the interpretive possibility that Aristotle thinks it is possible for one to overcome the limitations of human nature by acting in accord with the divine part of the soul. But this interpretation presents us with a further puzzle. According to Book 10, the divine part of us relates to the contemplative life, not the practical life. Yet, it seems that this interpretation implies that the more we live in accordance with our divine element, the better we can be as practical agents. I resolve this puzzle by suggesting that we must draw nearer Aristotle's conceptions of practical and the theoretical activity.

My investigation proceeds as follows. I begin by setting out the relevant details in NE 3.1 in order to put the overstraining passage in context. From here, I proceed by posing and answering a series of interpretative questions about the passage. Then, I consider Aristotle's comments in the $N E$ on human nature. And finally, I end by considering what he says about our divine nature and making the case that he thinks it is possible to identify with this aspect of ourselves thereby overcoming the limits of human nature. ${ }^{2}$

\footnotetext{
${ }^{2}$ In book 2 of the Eudemian Ethics Aristotle discusses voluntariness, the topic of $N E$ 3.1. Because his account in the $E E$ differs in important respects from his account in the $N E$, my interpretation is mean to be limited to the $N E$.
} 


\section{The context of the overstraining passage}

I begin with a sketch of the context of Aristotle's comments about situations that overstrain human nature. In the first chapter of Book 3 of the Nicomachean Ethics Aristotle sets out to

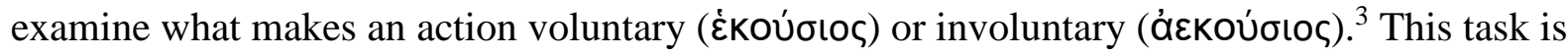
necessary for his ethical inquiry because, as he writes, virtue concerns feelings and actions, which 'receive praise or blame if they are voluntary, but are excused ${ }^{4}$ and at times even pitied, if they are involuntary' $(1109 \mathrm{~b} 30-32) .{ }^{5}$ Moreover, he claims that this analysis will also be useful to legislators in meting out honors and punishments.

Aristotle begins his analysis with the conventional view, according to which there are two ways that an action can be correctly considered involuntary. ${ }^{6}$ One is that it comes about through force $(\beta i \alpha)$. He elaborates that this means that the starting point for the action is external to the agent, who 'contributes nothing' to the event. His examples - being carried away by the wind or other people - make manifest the sorts of cases he has in mind here. The other is that the action is done because of ignorance. As Aristotle tells us later in the chapter, an action is involuntary if a person does not know what she is doing and comes to regret what she did when she realizes

\footnotetext{
${ }^{3}$ Kenny 1979, 27-28 rightly notes that the Greek terms extend beyond what in English we typically consider an action. Nonetheless, we can track what Aristotle means and nothing rides on this for my investigation.

${ }^{4}$ For a thorough discussion of 'excuse' as the best rendering of ' $\sigma u p \gamma v \omega \dot{\mu n}$,' see Phillips-Garrett 2017 (cf. Taylor 2006, 127 and 134-136).

${ }^{5} \mathrm{NE}$ translations follow Irwin 1999, with modifications.

${ }^{6}$ He writes that 'it seems' (ठокعĩ) that force and acting because of ignorance render the action involuntary. All indications are that he endorses these two conditions as the conditions of involuntary action, even if he proceeds to offer a refined account of voluntariness.
} 
what it was. ${ }^{7}$ This is contrasted with acting in ignorance-for instance, acting due to intoxication, anger, or ignorance of what is advantageous - which does not render the action involuntary.

Aristotle moves on from these straightforwardly involuntary actions to more problematic cases. It is one thing for a ship to get carried off by winds, an obvious example of an involuntary action due to external force, but what about cases where an agent finds herself in a situation where she must choose between two terrible options? These are cases not of force but of compulsion (ávópкn). The question that takes up the next part of the chapter, then, is whether compelled actions are voluntary or involuntary. ${ }^{8}$ One example Aristotle offers to illuminate what he has in mind is a ship captain who must jettison his cargo during a storm in order to save himself and his crew. Unlike the obviously involuntary action when the ship and its captain are physically moved, in such a case there is no force that necessitates the action. Nonetheless, such an action is not straightforwardly voluntary. So, Aristotle calls these 'mixed actions' because they seem voluntary and involuntary at the same time. ${ }^{9}$ Of this example he writes that no one would willingly throw cargo overboard absent such constraints, which makes the action seem involuntary. However, given the circumstances, the action is choiceworthy. Furthermore, in this case, because he is not forced, the starting point for the action comes from within the ship

\footnotetext{
${ }^{7}$ For discussion, see Sauvé 1989 and Whiting 1989.

${ }^{8}$ Aristotle offers different answers to this question in his discussions in the $N E$ and $E E$. See Sauvé Meyer 2011, 93-115 for discussion.

${ }^{9}$ Cf. Nielsen 273.
} 
captain, as he has to decide whether or not to jettison the cargo. Thus, Aristotle concludes, mixed actions are more like voluntary than involuntary actions. ${ }^{10}$

Aristotle's analysis of mixed actions is not yet complete, however. He next turns to a discussion of the different ways that we evaluate agents who perform mixed actions. Sometimes, he claims, that a person who performs a mixed action is praised. As he says, if something shameful or painful is endured for something fine, ${ }^{11}$ then the person is praised. In the opposite case-where something shameful or painful is endured for an end that is not fine, or only barely so-Aristotle says the person is blamed. Finally, he turns to the object of our present inquiry, situations that overstrain human nature. He writes:

In some cases, there is no praise, but excuse, whenever someone does something they should not on account of a situation that overstrains human nature and which no one would endure. But presumably there are some things that we cannot be compelled to do. We should rather die suffering the most terrible things. For, the things that 'compelled' Euripides' Alcmaeon to kill his mother seem laughable $(1110 \mathrm{a} 23-29) .{ }^{12}$

\footnotetext{
${ }^{10}$ Nielsen 280 maintains that 'mixed action' is not part of Aristotle's considered ontology. On her reading, Aristotle uses this label provisionally but ultimately identifies such actions as voluntary. I am inclined to agree. Cf. Cooper 2013,283, fn26.

${ }^{11}$ There is controversy as to whether we should understand these cases as actions the agent performs or situations that she passively endures. For discussion, see Nielsen, 283 (cf. Taylor, 133-134 and Kenny 1979, 33).

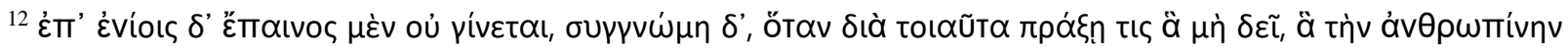

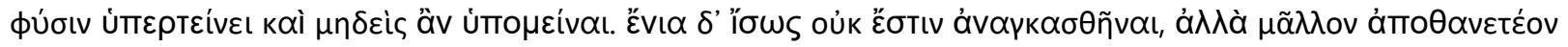

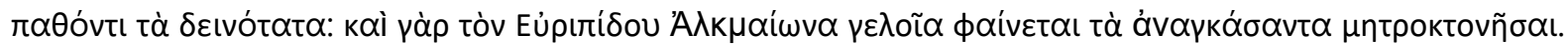


Aristotle's general point is easy enough to grasp. He is claiming that sometimes the circumstances are so extreme that they warrant leniency for someone, even if we do not approve of what they did. However, understanding the details of what Aristotle is saying, and so comprehending his point completely, is far from easy. In order to see this, and to begin to fully appreciate this claim, I now turn to a careful look at this passage.

\section{Interpretative questions about the overstraining passage}

In this section I will offer a comprehensive analysis of the overstraining passage. I will proceed by considering several interpretative questions about this passage. Although I will set them out individually, as we shall see, many of these questions are bound up together.

\subsection{Has the agent done something wrong in overstraining cases?}

It is always nice to start with an easy question. And this question seems like a softball. After all,

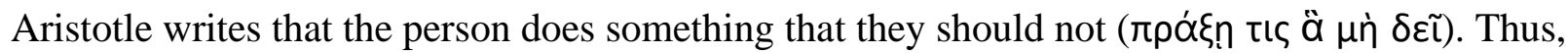
it appears unambiguous that Aristotle thinks that the person does something wrong. However, for two reasons, discerning Aristotle's view, even regarding this question, is complicated.

First, throughout his discussion of mixed actions, Aristotle distinguishes between the choiceworthiness of the action type and its choiceworthiness in the particular situation. Recall the paradigm case of a mixed action, the ship captain jettisoning his cargo to save his crew and himself. Throwing cargo overboard is something that one should not do, in general, but in this particular case, it is surely the right action. So, in one sense, it is true that the captain performs an action (i.e., an action type) that one should not do. But it is clear from Aristotle's discussion that, 
given the circumstances, the captain does what he should do in this particular situation. Hence, in another sense, the captain does what he should do and does not do anything wrong. So, the question is: in the overstraining case, does Aristotle mean that the person does what they should not do all things considered or merely that they do something that should not typically be done?

Based on the way Aristotle writes throughout this chapter, it is safe to conclude that he is offering an evaluation of the particular action rather than the action type. For instance, consider the two sorts of cases Aristotle discusses prior to the overstraining case. He indicates that when someone endures what is painful for a fine end, doing so is good. But if someone does so for an end that is not fine, they do something they should not. Both of these claims are about particular actions. So, in the overstraining case, we should take Aristotle to mean the particular action that the person performs is wrong, not merely that this is the sort of action that should not be done.

Still, there is a second reason to doubt that Aristotle thinks the person in an overstraining case does something wrong. The reason is that Aristotle writes that these agents are 'excused'

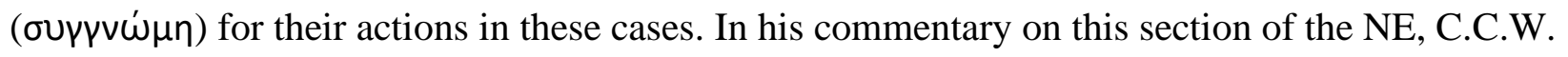
Taylor suggests that a true excuse indicates that the person did not do anything wrong (135). Taylor goes on to argue that because it would have been impossible for the agent to avoid performing this action — because the situation overstrains human nature and Aristotle says that no one would endure it — they have a sufficient excuse and so, they do nothing wrong. Thus, if this is correct, despite Aristotle's claim that the person does what they should not do, he must not really think that they have done anything wrong.

Below I shall investigate in more detail Aristotle's use of 'excuse' and consider whether Aristotle really thinks that it would be impossible to act otherwise in these cases. For now, though, I want to resist Taylor's view that the agent does not do anything wrong. Notice that 
Taylor infers that the agent does not do anything wrong from the claim that they are excused for the action. This inference is misguided for two reasons. One is that we can distinguish between two related but distinct issues: whether an action is right or wrong and whether the agent is accountable for the action. Indeed, this distinction is at the forefront of $N E$ 3.1. Throughout this discussion Aristotle is clear that a particular action can be good or bad in itself but this fact is separable from whether or not a person deserves credit or blame for it. Of course, in this chapter, his main examples deal with crediting and blaming based on whether the agent acted voluntarily or not. But he never says that this is the only fact that can pry these evaluations apart. Accordingly, we cannot necessarily move from an agent being let off the hook (as is the case when one is excused) to the conclusion that the action was not wrong. That is, Aristotle's view is that a person should not be punished for a bad action if it was done involuntarily, ${ }^{13}$ so we cannot infer from the fact that a person should not be punished the conclusion that there was no bad action. Hence, Taylor's inference is misguided.

This brings us to the second problem with Taylor's inference. Whereas he claims that an excuse indicates that the agent did not do anything wrong, the opposite is the case. An action is only excusable when there is something to excuse. And we do not excuse actions that should be performed; we only excuse actions that should not be performed. So, pace Taylor, any genuine excuse requires wrongdoing. ${ }^{14}$ Moreover, an excuse does not wipe away the wrong action, only

\footnotetext{
${ }^{13}$ Below I argue that in fact the agent in overstraining cases acts voluntarily.

${ }^{14}$ Compare this with the cargo case. As I said above, the action in this case is not wrong. We might be tempted to conclude that the ship captain is excused from doing what something wrong and so, conclude that excusing does not require wrong doing. I suggest, however, that this is not so. In the cargo case the conditions are enough to explain
} 
the accountability the agent would have for it, including any censure the agent would otherwise face. ${ }^{15}$ To see this, let us consider a much less serious case than an overstraining case: A person, Sam, being short with his friend, Michelle. If Sam has had a tough day and has been stressed out lately, then, as a decent person, Michelle will excuse him for responding to her in a slightly abrasive way. But friends should not be short with each other and the fact that Michelle excuses Sam's behavior does not erase what Sam did, even though it means that she will not hold it against him. So too, the agent in the overstraining case does something wrong but is excused from blame or any other consequences of the action. Accordingly, it seems clear that in these cases, the agent does something wrong.

\subsection{Are actions in overstraining cases voluntary?}

As we just saw, one factor in determining whether actions in overstraining cases are wrong is Aristotle's use of 'excuse.' This word also looms large for determining whether actions in these cases are voluntary. This is because our passage is not the first time in NE 3.1 that Aristotle uses this word. Recall that at the beginning of the chapter, he writes that voluntary actions are praised

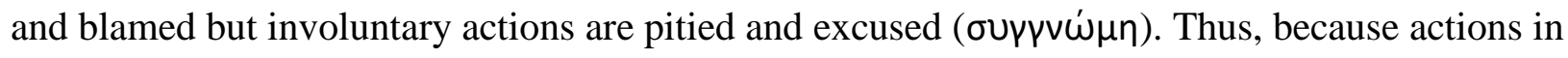
overstraining cases are excused, it seems that Aristotle thinks they are involuntary. ${ }^{16}$

\footnotetext{
why throwing the cargo overboard was not wrong. In contrast, the fact that an action has to be excused indicates that it was wrong.

${ }^{15}$ Recall that Aristotle says at the outset of this chapter that his discussion will be useful for determining honors and punishments.

16 Taylor 135.
} 
While this evidence suggests that actions in overstraining case are involuntary, it is not quite conclusive. The reason is that Aristotle's first lines in this chapter do not require that only involuntary actions are open to excuse. Instead, his claim is that involuntary actions are excused (and sometimes pitied). Thus, for all Aristotle says, it could be the case that some actions that are excusable are not involuntary but rather voluntary. ${ }^{17}$

If we consider what Aristotle writes elsewhere about oupyvúun, we have positive evidence that he thinks that voluntary actions can be excused. ${ }^{18}$ In $N E 6.11$ (=EE 5.11) Aristotle says that excusing requires knowing how to determine what matters for decency and that the decent person is above all the person who is good at determining when excuse is warranted (1143a20-23). ${ }^{19}$ Furthermore, in NE 5.10 (=EE 4.10) Aristotle spells out the relationship between decency and justice. His view is that decency is required to correct judgements in cases

\footnotetext{
${ }^{17}$ Aristotle also writes that voluntary actions are praised or blamed. But again, he does not say that all voluntary actions are either praised or blamed. Instead, we can take him to be stating what is generally the case. See Taylor 135-136 for an opposing view (cf. Müller, 2015, fn. 55). It is also important to remember that Aristotle begins with the conventional conditions that make an action involuntary, which he goes on to refine. Accordingly, we should not be surprised if Aristotle likewise refines how we should evaluate certain kinds of actions as the chapter proceeds. Indeed, the fact that he goes on to introduce mixed actions might suggest that this is his strategy. See Klimchuck 78 and Hursthouse 1984, 257-8, who argues convincingly that Aristotle could not have intended the opening line to be without exception.

${ }^{18}$ My discussion of Aristotle's view of excuse benefits from Phillips-Garrett 2017. However, we reach different conclusions, as it seems that she takes actions in overstraining cases to be involuntary.

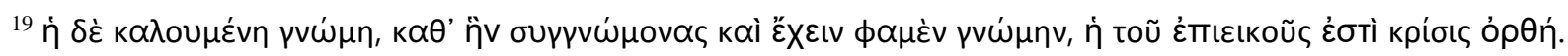

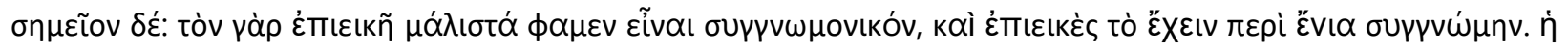

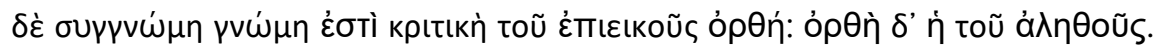


where the law gets an evaluation wrong. Because the law must be universal, it is deficient and will necessarily get some of cases wrong due to their particulars. The decent person is able to determine when this happens, judging that although the law deems someone is blameworthy, they should be excused. None of this requires, or even suggests, that excuse is only given to people who act involuntarily. Indeed, that would be surprising and in fact rather preposterous, since there are any number of ways that a law might be insensitive to the particulars of a situation, most of which have nothing to do with whether force or ignorance is involved.

So, Aristotle's use of 'excuse' in the overstraining passage does not imply that actions in these cases are involuntary. But there is a further argument that they are. Taylor argues that two of Aristotle's claims lead to this conclusion. First, Aristotle writes that voluntary actions are 'up to the agent.' Second, Aristotle writes that no one would endure these situations, which Taylor takes to imply that acting otherwise in overstraining cases is impossible. ${ }^{20}$ Thus, he argues, Aristotle must think that actions in these cases are involuntary (136).

Below I shall consider whether Taylor is correct in his contention that Aristotle maintains that acting otherwise is impossible in overstraining cases. For now, though, I will focus only on his claim that actions in overstraining cases are involuntary. And although formidable, this interpretation faces several problems.

First, Aristotle does not think that just because an agent could not do otherwise in a particular situation, she acts involuntarily. For instance, he seems to hold that a vicious person may find it impossible to refrain from a vicious action, but she still does it voluntarily. ${ }^{21} \mathrm{~A}$

\footnotetext{
${ }^{20}$ Cf. Everson 1990, 93.

${ }^{21}$ See Broadie 144 (cf. 1110b13-14 and 1114a13-21). For a thorough treatment of this issue in its own right, see Kamtekar 2019.
} 
second, related point is that Aristotle thinks that an action being 'up to the agent' is based upon whether or not the action originates from within the agent (1110a15, cf. EE 1124b12-15). In summing up his discussion of force, Aristotle makes it clear that what makes forced actions involuntary is that they originate outside of the agent (1110b18). But Aristotle gives no indication that this is so with actions in overstraining cases. Instead, the fact that it is the agent's human nature that causes them to act suggests that the action originates from within them. ${ }^{22}$ In addition to the foregoing, there are two further reasons to think that actions in overstraining cases are voluntary. One is that immediately after introducing the idea of being overstrained, Aristotle says that there are actions we cannot be compelled to do but that we would rather suffer a painful death than perform. This suggests that even in genuinely overstraining cases the agent has to judge that the action they are about to perform is not one that we "cannot be compelled to do. ${ }^{23}$ The other-and I think definitive—reason to believe that actions in overstraining cases are voluntary is the context of the discussion. As we have seen, immediately prior to the overstraining case, Aristotle claims that sometimes people are praised for enduring painful or shameful things for noble ends but they are blamed when doing so for less noble ends. It is obvious that these are meant to be mixed actions, the category that Aristotle has just introduced. When he brings up overstraining cases, he does not indicate that he has

\footnotetext{
${ }^{22}$ See Sauvé Meyer 2011 p. 100. Müller 2015 argues that in the EE Aristotle's view is that even if the principle of action comes from within the agent, if it is due to human nature, rather than her particular nature, the action is compelled. cf. Everson 1990 for a similar reading of this issue in the $N E$.

${ }^{23}$ So, pace Taylor 140, in overstraining situations the agent must consider reasons for and against acting.
} 
moved away from discussing mixed actions. ${ }^{24}$ Indeed, the fact that all of the sentences in this passage, including the sentence that mentions overstraining situations, are connected with $\delta \varepsilon$ 's $^{\prime}$ indicates that this is all part of a single elaboration on mixed actions. Hence, actions performed in situations that overstrain human nature are mixed actions, which means that Aristotle takes them to be voluntary, or at least more like voluntary actions that involuntary actions. ${ }^{25}$

\subsection{Is there a right action in overstraining cases?}

Based on the foregoing, we can conclude that Aristotle thinks that in overstraining cases the agent does something wrong and does so voluntarily. From this it may seem to follow immediately that there is a right action open to the agent in these situations. After all, doing something wrong typically implies that there was a right action open to the agent.

However, we cannot safely jump to this conclusion. This is because the possibility of moral dilemmas undermines the implication. That is, if moral dilemmas are possible, then the fact that an agent does something wrong may not imply that a right action was available. Indeed, some scholars argue that Aristotle's discussion in NE 3.1 betrays a commitment to the existence of moral dilemmas. ${ }^{26}$ If this is correct, then, perhaps Aristotle thought that in situations that overstrain human nature, there are only bad choices available to an agent. And maybe this is just what he is trying to capture in claiming that human nature is overstrained. So, we must now consider whether Aristotle has moral dilemmas in mind in the overstraining passage.

\footnotetext{
${ }^{24}$ I presume this observation is what leads Irwin 1980, 137 to claim that actions in overstraining cases are voluntary (cf. Kenny 1979, 29).

${ }^{25}$ Recall (fn. 9 above) that if Nielsen is correct, so-called 'mixed actions' are in fact fully voluntary.

${ }^{26}$ In particular, Nussbaum 1986 and Stocker 1986. For opposing views, see Nielsen and Gottlieb 115-134.
} 
There is much disagreement in the literature on what constitutes a moral dilemma.

Minimally, moral dilemmas involve a conflict between moral duties, obligations, or virtues. ${ }^{27}$ Michael Stocker is a proponent of the view that Aristotle endorsed the possibility of such conflicts, arguing that Aristotle's mixed actions 'dirty an agent's hands.' On his reading, such situations force an agent—even a good agent — into doing something wrong and shameful. As a result, the person is left with 'dirty hands' and reason to feel regret.

Can this be the correct way to understand what Aristotle thinks about actions in overstraining cases? It seems not, even if Stocker is correct that this is how to understand other kinds of mixed actions. ${ }^{28}$ On his view, an action that dirties the agent's hands '(1) is right, even obligatory, but (2) is none the less somehow wrong, shameful, and the like' (51-52). So, dirty hands actions are right, all things considered, even if they require the agent to perform a shameful action. This might fit the cases where someone endures something painful or shameful for the sake of a fine end, but it does not fit overstraining cases. As argued above, in these cases, the agent does something all things considered wrong, which is why she must be excused.

So, according to Stocker's 'dirty hands' account of moral dilemmas there is a right action available. However, this account cannot be the correct way to conceive of overstraining cases. Let us, then, consider the more robust notion of moral dilemmas, according to which a moral dilemma is a situation where morality equally prohibits any course of action open to the agent. ${ }^{29}$ In this type of moral dilemma there is no right action open to the agent. Perhaps the most famous example of such a dilemma is Sophie's choice. In this case, a mother is forced to choose which

\footnotetext{
${ }^{27}$ See McConnel 2018. Gottlieb calls these 'resolvable dilemmas' (117).

${ }^{28}$ See Nielsen and Gottlieb for reasons to resist.

${ }^{29}$ These are often referred to as 'tragic dilemmas'. Gottlieb helpful calls them 'irresolvable dilemmas' (117).
} 
of her two daughters will be killed and if she does not choose, both will die. Here, it seems that there is no right action open to Sophie. Importantly for our purposes, several aspects of this case conform to my analysis of overstraining cases. Given that she has to choose, it is fair to say that Sophie acts voluntarily in making her choice, even though it is a compelled choice. While I find it difficult to say that she acts wrongly, there can be no doubt that the outcome is horrible but that we would excuse Sophie for her decision. If these are the sorts of cases Aristotle has in mind as overstraining human nature, then it looks like we should conclude that he does not think that there is a right action available to the agent in such cases.

The pressing issue now becomes whether in this passage Aristotle has in mind situations like Sophie's choice. Unfortunately, Aristotle's explicit remarks about situations that overstrain human nature do not indicate one way or another. But if we look elsewhere, I believe that we can find strong evidence that Aristotle does not have these sorts of dilemmas in mind.

We can start with what immediately follows the overstraining passage. Here, Aristotle considers the case of Euripides's Alcmaeon, who kills his mother in order to avoid a curse from his father. Aristotle claims that Alcmaeon's defense that he was compelled to do so is ridiculous because there are some things that we cannot be compelled to do. Rather than perform such actions, Aristotle writes that we would die suffering the most terrible things. I take it that Alcmaeon incorrectly seeks excuse, citing that he had to kill his mother because the situation overstrained human nature. ${ }^{30}$ But notice what the choices are: commit matricide or be cursed and presumably die. More generally, the choice is between doing an evil action or suffering something personally bad. An unpleasant decision indeed! But one that is very different from Sophie's choice (or any kind of moral dilemma), where the conflict is between two morally bad

\footnotetext{
${ }^{30} \mathrm{I}$ discuss this case in more detail below.
} 
acts. Being cursed and dying is surely personally bad, but it is far from clear that allowing this to happen to oneself is morally bad.

If we turn to the parallel discussion in the $E E(2.8)$, we see something similar. ${ }^{31} \mathrm{At}$ 1225a3 Aristotle writes that someone acts under compulsion, 'when they do something they consider painful and vicious but are threatened with flogging, imprisonment, or death if they do not do it. ${ }^{32}$ According to what he says, mixed actions (even if he does not refer to them as such $)^{33}$ involve a conflict between doing something vicious or painful and suffering something painful, up to and including death. Thus, as in the Alcmaeon case, there is not a conflict between the demands of virtues, but between virtue and pain and personal suffering. Hence, in the parallel passage in the $E E$, Aristotle is not entertaining any kind of moral dilemma.

One might be chary about extending what Aristotle writes in the $E E$ passage to the $N E$ passage on overstraining situations, since the latter is about mixed actions in general, not overstraining situations in particular. But two factors militate against this concern. First, as we have seen, overstraining cases are particular types of mixed actions. So, since Aristotle in the $E E$ holds that mixed actions in general involve conflicts between demands of virtue and personal suffering, he must think that this is the case with overstraining situations. Second, a few lines later in the $E E$ Aristotle mentions conditions that can overpower human nature. He writes that

\footnotetext{
${ }^{31}$ Although there are important differences between the $N E$ and $E E$ discussions - for instance, in the $N E$ Aristotle argues that compelled actions are voluntary, whereas in the $E E$ he argues that they are involuntary—my concern here is with the structure of the examples Aristotle employs. For a thorough treatment of the differences between these passages, see Sauvé Meyer, 93-115.

${ }^{32}$ Kenny translation.

${ }^{33}$ Cf. Nielsen, 273
} 
sexual passion and types of anger and physical conditions are taken to overpower ( $\beta ı \alpha \zeta \varepsilon \sigma \theta \alpha \mathrm{l})$ our (human) nature (1225a21, cf. 1225a35). Importantly, he continues that for this reason, we

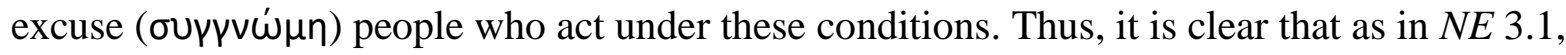
here in the $E E$ Aristotle has on his mind situations that demand more than human nature can bear. This suggests that it is reasonable for us to extend the $E E$ passage to the $N E$ passage. And if we only focus on what Aristotle says about human nature being overpowered in the $E E$, we can see that again that he is not thinking about conflicts between demands of virtue.

So, the details Aristotle provides in the $N E$ and the $E E$ indicate that he does not take overstraining situations to be moral dilemmas of any kind. If we turn to the Politics, we can find more support of this contention. In Politics 3, entertaining the possibility of a king disinheriting his son who would be a disastrous ruler, Aristotle writes, 'Yet this is not easy to believe: it would be grievous and an act of virtue greater than the virtue of human nature' $(1286 \mathrm{~b} 25-27) .{ }^{34}$ Here, it looks like we have an example of a situation that overstrains human nature. Unlike the above examples, this case could be cast as a moral dilemma, although one unlike Sophie's choice. We might say that in this case the demands of care for one's children conflict with the duties of a good ruler. But this does not seem to be the way that Aristotle analyzes this case. Instead, the conflict is between being a good ruler to the city and the pain ( $\chi \alpha \lambda \varepsilon \pi$ ó $)$ that he would face in disinheriting his son. Thus, as with the other cases above, this case in the Politics is a conflict between doing the right thing and personal suffering.

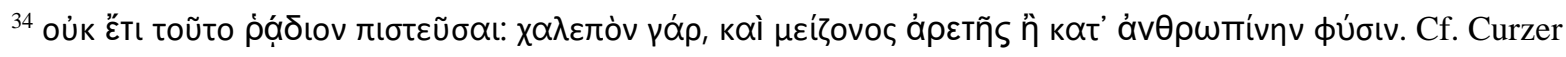
2005,238
} 
After reviewing these passages, it is safe to conclude that Aristotle does not conceive of overstraining cases as moral dilemmas of any kind, let alone dilemmas similar to Sophie's choice. Thus, we have no reason to think that he envisions overstraining cases as situations where there is not a morally good option open to the agent. It is fair, then, to consider what is implied by what Aristotle does say. As we have seen, it seems that Aristotle's view in these cases is that the agent has voluntarily done something wrong. And since it is not his view that all of the options open to the agent are wrong, he must think that there is one of the options is (morally speaking) right.

This analysis of overstraining situations seems to be bolstered by the relevant examples Aristotle provides. In the Alcmaeon case-which Alcmaeon would purport to be a situation that overstrains human nature - there is a right action, namely risking (or even accepting) the curse. In the discussion in the $E E$, surely Aristotle would say that it would be better if the agent could resist her sexual passion or anger, even if we excuse her for giving in. Finally, the case from the Politics is the clearest example; the king should disinherit his son, who would be a disastrous ruler. Indeed, this evaluation is explicit, as Aristotle indicates that doing so would be an act of virtue, albeit one that goes beyond human nature. ${ }^{35}$ Thus, as we have seen, in at least some situations that overstrain human nature, there is a right action available to the agent.

\subsection{Is Aristotle making descriptive or normative claims here?}

At times in this passage Aristotle appears to be describing what is the case, while at other times he seems to be prescribing what should be the case. But typically, we think that how people act

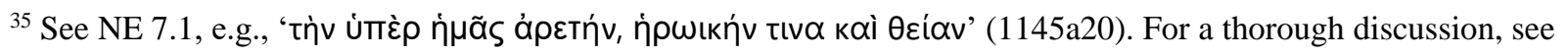
Reed (cf. Broadie 1991, 144).
} 
can differ from how they should act, and vice versa. So, the question arises: does Aristotle take himself to be describing how people act or how we should act?

This question applies to several aspects of this passage. First, is Aristotle saying that people in these situations are excused or that they should be excused? He writes that people are excused for these actions, which makes his claim sound descriptive. If Aristotle is correct about situations that overstrain human nature, then ideally anyone who found themselves in one would be excused. But of course, there is no guarantee of this, and indeed, it is unlikely that everyone in such situations would, in fact, be excused. Third-party observers may lack relevant facts ${ }^{36}$ or might have character flaws that lead them to judge the agent more harshly than they should. ${ }^{37}$

So, Aristotle's claim cannot be straightforwardly descriptive. Instead, we can take him be saying that we should excuse a person in such a situation. Similarly, we might take Aristotle's view to be that the agent is excused as meaning that the agent deserves excuse, even if she does not receive it. On this reading, Aristotle is claiming that the person is excused whether or not third parties recognize that she is. A further possibility is that Aristotle might think that fully informed virtuous agents would excuse the agent. On this reading Aristotle is offering a

\footnotetext{
${ }^{36}$ Indeed, a bit later in the chapter Aristotle remarks on the difficulty of determining what is to be done in mixed action situations $(1110 \mathrm{a} 30,1110 \mathrm{~b} 7)$. Surely, he thinks this applies not only for the agent, but for third parties judging an agent. As an anonymous referee suggested to me, Aristotle's claim here may also provide support for my contention above that there is a right action available. The fact that it is difficult to determine what one should do in these situations - including overstraining situations, presumably - indicates that there is a fact of the matter about what should be done (i.e., the right action).

${ }^{37}$ As discussed above, Aristotle thinks that that the decent person is skilled in knowing when excuse is warranted. This indicates that others are not skilled at knowing when to excuse people, and so, likely fail to excuse when it is warranted.
} 
description of what a type of person would do, but given that Aristotle sets out the virtuous agent as the standard of how we should act, it carries normative force. On any of these readings, then, Aristotle is making a normative claim, even if he presents it as descriptive.

This question arises most pressingly when we set Aristotle's initial remarks on overstraining cases alongside what he says about the Alcmaeon case. When Aristotle initially mentions situations that overstrain human nature, he appears to be making a psychological, and so, descriptive claim. His point seems to be that there are some situations that no human can bear, given our built-in psychological limits. But in the Alcmaeon case, Aristotle appears to make a normative claim. He says that there are some actions - for instance, matricide - that we could not be compelled to perform but would rather die. Yet, he also writes that Alcmaeon was

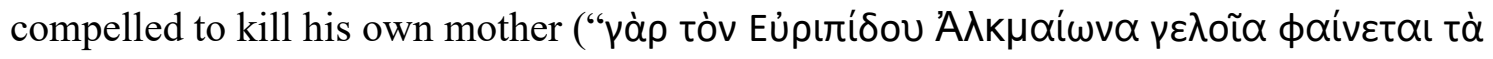

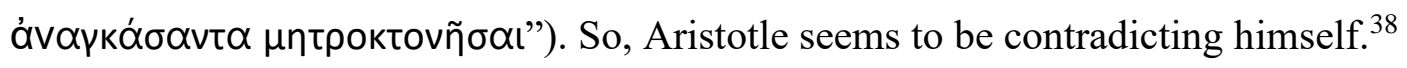

In resolving this apparent contradiction, we can make headway on determining what kind of claim Aristotle is offering. Let us see how.

There are two ways to extricate Aristotle from this (apparent) contradiction. One is to read him as restricting the first claim to himself and his audience. On this reading, Aristotle is effectively saying, 'we (i.e., well-brought up and virtuous people) could not be compelled to commit matricide, even if others could. ${ }^{39}$ The problem with this reading is that it is unnatural to

\footnotetext{
${ }^{38}$ Sauvé Meyer 20112011, 99-100 raises a related but different problem. She distinguishes between rational and psychological compulsion and argues that the first overstraining cases is an instance of the latter but that in the Alcmaeon case Aristotle invokes the former. Cf. Broadie 144.

${ }^{39} \mathrm{Cf}$. Hursthouse, 261-262.
} 
think that Aristotle has a restricted 'we' in mind given that he was just talking about humans in general and he does not indicate any restriction.

The other reading is that Aristotle does not think that Alcmaeon was in fact compelled to commit matricide, even if Alcmaeon thought he was. As is evident from my use of scare quotes around compelled in my translation above, this is my preferred reading. ${ }^{40}$ Although Aristotle does not directly indicate that this is what he means, it is indirectly supported by his claim that compulsion is a laughable defense in this case.

If my strategy for resolving this contradiction is correct, then Aristotle is saying that there are some things that humans cannot be compelled to do. The only way to understand this is as a normative claim; Aristotle must be saying that there are some things we should never do, no matter how bad the circumstances and consequences (for us) if we do not do them. ${ }^{41}$ But there is still a problem: if it is (descriptively) true that when human nature is overstrained performing a certain action is irresistible, then it does not seem that Aristotle can say definitively that there are certain actions we cannot be compelled to perform. After all, if our human nature is overstrained, then it seems that we could be compelled to do anything. So, how is it that the badness of the action determines whether or not we can be compelled to perform it?

\footnotetext{
${ }^{40} \mathrm{Cf}$. Irwin's translation and Taylor's translation.

${ }^{41}$ See Klimchuck 8-9 and Cooper 2013, fn. 29. Nielsen 285-6 argues that Alcmaeon could not have been compelled to kill his mother because such an action is always wrong. I agree, but my interpretation furnishes us with an explanation of why we cannot be compelled to perform such actions. As I argue below, Alcmaeon could not be compelled on account of human nature being overstrained because human nature cannot be overstrained to the point to compel someone to act contrary to human nature.
} 
I would venture that Aristotle's view is that some actions are so antithetical to human nature that no matter the alternative, we could not be compelled to perform them. ${ }^{42}$ That is, performing such actions would not merely overstrain human nature, it would be contrary to human nature. Thus, it is fair to say that one could not be compelled to perform an action such as matricide, even if doing so would be the only way to avoid risking a curse. Of course, one can commit matricide. But one would have to be flawed to perform such an action. That is, performing such an action would be caused not by human nature being overstrained — for human nature could not be overstrained to the point to do something that is contrary to human naturebut by a failure in the character of the agent. ${ }^{43}$ Thus, Aristotle's view seems to be that given our nature, there are some situations that we cannot bear such that if we act badly in them, it is excusable. However, that very same nature is what makes it so that we would rather die than perform certain actions.

So, in this passage, Aristotle has a robust conception of human nature. And, it is reasonable to say that for Aristotle, human nature is not a merely descriptive concept. Instead, on his view, human nature is normative. Of course, this is not surprising, given his teleological view of the world. Moreover, it is clear throughout his ethical works that human virtues derive from our nature. Accordingly, it follows that if our human nature cannot bear a situation, then even if

\footnotetext{
42 Kenny 1979, 34 offers similar explanation. On his view, the description of the action may depend on moral considerations of what should have been done.

${ }^{43}$ See Nielsen 298 (Cf. Müller 2015, 243.). And a person with a flawed character could perform such an action believing that they were compelled to do so, as is, apparently, the case with Alcmaeon. However, the fact that one thinks one is compelled does not make it so, just as the fact that some people think an agent is not excused does not make it so.
} 
we are compelled to perform a bad action, not only should we not be punished, it is also not a mark against our character. But also given our nature, there are some actions that we should never perform, and that a decent person would never perform nor could be compelled to perform. The situation the person is facing may be exactly the same as a genuinely overstraining situation, but if the potential action is contrary to human nature, then the only way one could perform it would be due to a vice. Thus, unlike a genuinely overstraining case, such an action is not truly compelled and performing it reveals a serious character flaw.

\subsection{Does Aristotle think anyone can act well in overstraining situations?}

The final interpretive question is whether Aristotle thinks it is possible for someone to perform the right action in overstraining situations. Given that he writes that these are situations that 'no

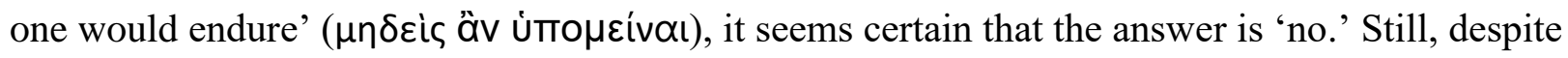
how Aristotle makes his point here, there is some reason to think that he might allow for the possibility that a very rare person could perform the right action, even in these cases.

First, Aristotle reminds us throughout the $N E$ that ethical propositions are open to exceptions $(1094 \mathrm{~b} 12-27,1098 \mathrm{a} 25-34,1104 \mathrm{a} 1-7) .{ }^{44}$ Furthermore, a generalization suits Aristotle's purposes in this passage better than would perhaps a more accurate but more complicated claim. In this chapter Aristotle is trying to sort out the knotty issue of voluntariness and in this stretch he is concerned with the knottiest aspect of the discussion, mixed actions. ${ }^{45}$ His point in this passage is that sometimes we excuse people for doing what they should not do

\footnotetext{
${ }^{44}$ Cf. Drefcinski 1996, 142, Curzer 2005, 235, and Reed 2017, 108-109.

${ }^{45}$ Indeed, an issue about which it seems Aristotle himself has changed his mind, given the differences between the $E E$ and $N E$.
} 
in exceedingly trying situations. It would not serve him to entertain the possibility of very rare cases where a very rare person might do the right thing in a situation like this. Rather, given his point, it makes sense for him to speaking in generalizations. It is generally true that no one would act well in these situations. But this is consistent with the possibility that someone could. ${ }^{46}$

Second, this is not the only passage in this chapter where Aristotle makes a broad claim that no one would perform a certain kind of action in a certain kind of situation. Just a few lines earlier, he claimed that mixed actions are such that no one would perform them in their own right (1110a19, cf. 1110a8). ${ }^{47}$ But strictly speaking, this is false. Such actions might be in themselves unchoiceworthy but it does not follow that no one would choose them in themselves. It may well be true that the overwhelming number of people would not perform such actions in their own right. And it is likely true that no one with any sense would do such actions in their own right (cf. 1110a8). But surely there are people, including vicious people and people without sense, who would knowingly do such actions in their own right. And surely Aristotle would agree that there are such people. So, character is relevant. ${ }^{48}$ Someone with a bad character might well choose such actions in their own right. As we saw in the analysis of the Alcmeaon case, character also makes the difference as to what sorts of actions one might be 'compelled' to perform.

\footnotetext{
${ }^{46}$ Cf. Reed 2017, 109.

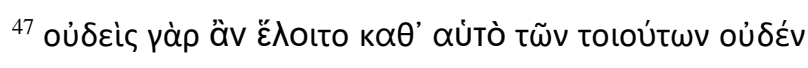

${ }^{48}$ Hursthouse 1984, 259-60 suggests that Aristotle really does mean that no one would perform such actions. But this is because she reads an interpretation into the examples. For instance, she reads Aristotle as claiming in the jettisoning cargo case that no one would do what is wasteful under that description. But this is not what Aristotle writes. He does not say that no one would do what is wasteful. Instead, he simply writes that no one would throw cargo overboard (1110a10). So, Aristotle is best taken as speaking generally.
} 
Third, Aristotle does not write that no one could endure situations that overstrain human nature, and so, perform the right action in them. If this were his thought, then he could have written it. Instead, we should take him as making a general point about what is likely to happen in these cases, not what (psychologically) must happen. Now, he might think that most people could not perform the right action in these cases, due to our human nature. But again, this is consistent with the possibility that someone could.

The foregoing shows that despite initial appearances, we do not have to rule out the possibility that Aristotle thinks that someone could act well in an overstraining situation. Our answers to the earlier interpretive questions above give us some positive reason to conclude that Aristotle thinks that it is possible for someone to do the right thing in at least some of these cases. After all, as we have seen, Aristotle does think that there is a right action available to agents in these situations. Moreover, even though their actions are understandable, and so, excusable, Aristotle thinks that agents in these situations voluntarily choose to do what they should not. That is to say that the principle of the action is within the agent. Thus, in some sense, it is possible that an agent might choose otherwise. And while perhaps most agents would give in to situations that overstrain human nature, this leaves open that a small number might not.

As we have seen, in overstraining cases the agent acts badly because their human nature is overstrained. Accordingly, in order for someone to act well in such a situation, Aristotle would have to think it is possible for a person to overcome the limits imposed by human nature. Based on my analysis of the Alcmaeon case above, we know that Aristotle does in fact think that agents can act contrary to human nature. So, the question is, could an agent resist her human nature but in doing so perform the right action? If so, how would this be possible? 
In the remainder of this paper, I want to take up these questions. Before setting out my argument, let us make explicit the relevant sorts of situations that overstrain human nature. We can do so based on the sorts of examples Aristotle gestures at. As we have seen, these examples involve pain or fear. For instance, in the EE Aristotle mentions threats of flogging and death. Of course, as we know from the Alcmaeon case, such threats do not overstrain our human nature if the alternative is antithetical to our humanity. Thus, the cases in question cannot be ones in which the agent faces flogging lest they commit matricide. So, instead we might consider a case in which someone must face or endure horrible torture if she refuses to give up sensitive political secrets. In this case, we would excuse her if she gave in to the torture and divulged the secrets, for the fear and pain would be too much for our human nature to bear. Or we might consider the case that Aristotle offers in the Politics, where a king cannot bear the pain of disinheriting his son because doing so would require 'an act of virtue greater than human virtue.' Again, even if it is hard to believe that someone could make the right decision in this case, Aristotle invites us to do so by telling us what would have to be the case in order for this to obtain: the king would have to act with a virtue greater than human. ${ }^{49}$ But how could this be? And how could someone resist torture that overstrains human nature? I will argue that Aristotle thinks that it is possible for someone to go beyond their human nature in such situations by acting in accordance with another aspect of themselves, their divine nature.

\footnotetext{
49 This case, coupled with Aristotle's claim in NE 7 that some people do have virtue that extends beyond our nature

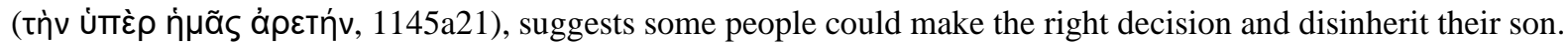
Hence, Aristotle must think it is possible to act well in situations that overstrain human nature. Cf. Cooper 2013, 286.
} 


\section{Overcoming human nature}

I just have argued that there is reason to believe that Aristotle would allow that some people could act well in situations that overstrain human nature. I must now show how it would be possible to act well in these situations. As we shall see, by acting in accord with the divine part in us, rather than our human nature, we can act well in cases that otherwise overstrain our human nature. In order make the case for this claim, I must set out what Aristotle says about our human nature and our divine element in the $N E$. I begin with the former.

\subsection{Human nature}

As we have seen, in our central passage, Aristotle indicates that human nature sets certain limits on what we can be expected to tolerate. As we have also seen, implicit in this passage is the idea that our human nature likewise determines the limits of compulsion, as there are some actions so contrary to human nature that a reasonable person would rather die than perform them. These are not Aristotle's only comments on human nature. Here, I will draw together Aristotle's other claims about human nature in the $N E$. As we shall see, most of these comments come in the course of discussing courage and temperance, and so, fear and appetite.

In chapters 6-9 of Book 3, Aristotle turns from prerequisites for virtue, including his analysis of voluntariness, to a discussion of courage. Early in chapter 7 Aristotle claims that although different things are frightening to different people, 'some frightening things exceed human beings' and these are frightening to everyone with sense (1115b6). He reiterates this point in the next line, referring to fearful things that do not exceed human nature ( $\tau \dot{\alpha} \delta \varepsilon \dot{\varepsilon} \kappa \alpha \tau^{\prime}$

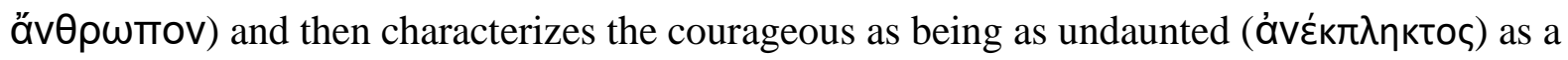
human being can be by what is frightening. All of this suggests that our human nature is such 
that certain things - which Aristotle does not identify but presumably relate to death given the scope of courage - are too scary for us to face. ${ }^{50}$ While given their own dispositions, etc., some people are afraid of heights and others afraid of enclosed spaces, Aristotle thinks that our shared nature makes us all fear, for instance, being drawn and quartered. Not only does this passage tell us a bit more about Aristotle's view of human nature, it also reinforces what we saw him say about situations that overstrain our nature. Surely one would be excused for fleeing a situation that is too frightening for a human to bear (if that is the reason she fled).

Aristotle returns to these issues in the next chapter. He writes that professional soldiers

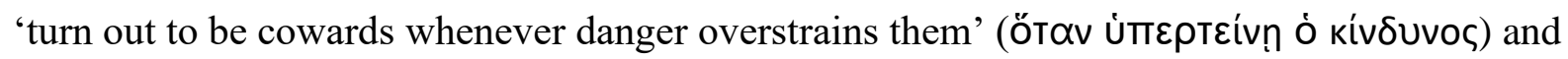
are the 'first to run' because 'they were facing the danger on the assumption of their superiority, once they learn their mistake, they run, since they are more afraid of being killed than of doing something shameful' (1116b16-20). As in our central passage, Aristotle here mentions overstraining. Notice, though, that in this passage, it is the professional soldiers, not human nature that is overstrained. This indicates that the weakness lies with the soldiers' individual characters, not human nature. Indeed, Aristotle's point is that they are overstrained on account of their peculiar psychology. There are certain limits to what humans can take given what human nature is. The professional soldiers Aristotle discusses have a limit that falls short of the limit imposed by human nature, and this limit is due to their habituated psychological condition. According to what Aristotle writes, the soldiers have confidence but when they are outnumbered, it is dissolved and replaced with fear. This replacement is possible because their confidence is based on the belief of advantage. In contrast, the psychological condition of the genuinely

\footnotetext{
${ }^{50}$ This is not to suggest all types of death are too frightening for human nature, as the courageous person faces death. Perhaps Aristotle has in mind certain ways of dying, or certain consequences that might result from dying.
} 
courageous person enables them to remain both undaunted and in their position in the face of being at a disadvantage. They will not be overcome by fear within the human limit because the courageous person 'stands firm against what is and appears frightening to a human being' (1117a16). This indicates that unlike the psychological limit of professional soldiers, the psychological limit of the courageous person coincides with the human limit, meaning that the courageous will only be overstrained by fear that exceeds the human limit. ${ }^{51}$

Aristotle's final topic in Book 3 is temperance. As with his discussion of courage, some of his comments about temperance invoke human nature. For instance, in chapter 11 he writes that while some appetites are peculiar to certain people, there are some appetites that are shared

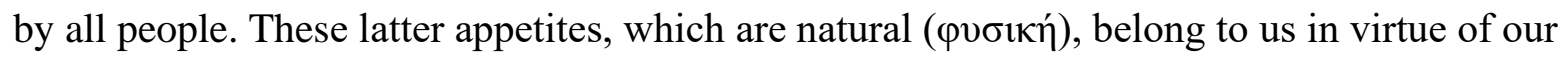
human physiology because we cannot help but have an appetite for food when we have gone too long without eating (1118b12).

Even though Aristotle thinks that only certain kinds of appetites belong to us in virtue of our human nature, he also claims that part our human nature is to have distinctive appetites. He reasonably holds that something that is pleasant for one person is more likely to be pleasant for others than something chosen at random would be (1118b14). This indicates that Aristotle thinks

\footnotetext{
${ }^{51} \mathrm{My}$ analysis here reinforces my contention above that even in overstraining cases, the principle of the action comes from within, making the action voluntary. It is clear in the case of the professional soldiers that the action is caused by their psychology. But this is also the case with the courageous person in a situation that is too frightening for a human to bear. For the professional soldier, the cause is their own peculiar psychology, whereas for the courageous person it is the psychology hard-wired into (though open to alteration) human nature. Nonetheless, in both cases, the cause of the action is within the agent. See also EE 1125a26: 'what is in a man's power-and it all

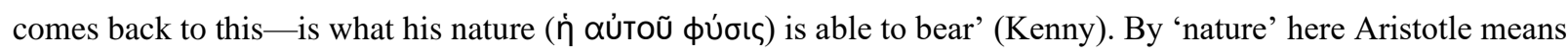
the individual nature that a person has cultivated for themselves through habit. Cf. Müller 2015, $220 \mathrm{ff}$.
} 
that there is a general range of distinctive appetites built into human nature. Moreover, he claims that an utter lack of discrimination when it comes to pleasures is not human and that someone who 'finds nothing pleasant or preferable to anything else... is far from being human' (1119a8).

Aristotle alludes to his comments about natural appetites in his discussion of incontinence in Book 7. At 1149b5 he claims that natural appetites and desires are common to most and adds the new claim that they are better to follow. A bit later, explicitly referring back to 'what we said

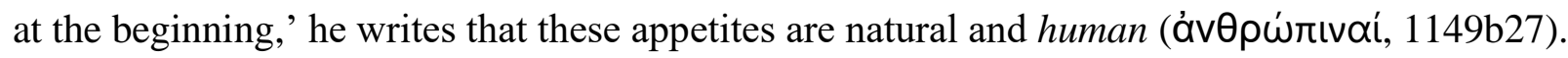

In at least one other passage, outside of his explicit discussion of fear and appetites, Aristotle mentions human nature. In his treatment of generosity, he claims that stinginess

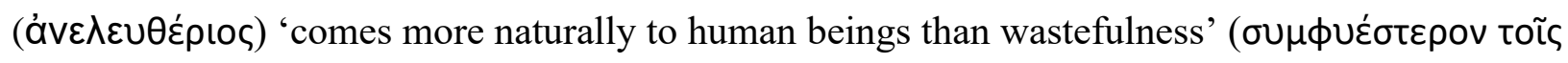

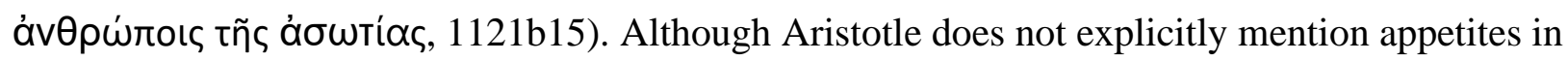
this passage, he does implicitly refer to them. For, he says that stinginess is more natural because

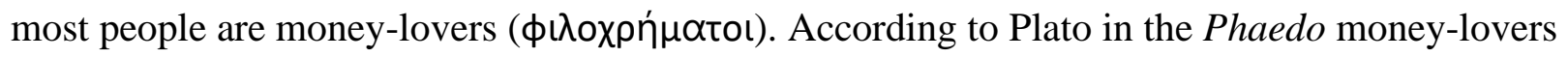
value bodily pleasures more than anything else $(68 \mathrm{~b} 7-69 \mathrm{e} 4$ and $80 \mathrm{c} 1-84 \mathrm{~b} 5)$. So, Aristotle's use of this word here indicates that the reason stinginess is more natural for us is because humans naturally want to be able to satisfy their bodily appetites.

So, it seems that most of Aristotle's comments about human nature come in the context of broader discussions of fear and appetites. On his view, it seems that our human nature provides us with natural objects of fear and appetites, and part of what it is to be human is to have these. This complements my findings above about situations that overstrain human nature. 
As we saw, Aristotle's examples of such situations focus on fear, pain, and even appetites as the sorts of conditions that can overstrain human nature. ${ }^{52}$

Finally, it is also worth noting that at the beginning of his treatment of temperance, Aristotle comments that courage and temperance seem to be the virtues of our nonrational parts (1117b25). This, coupled with the fact that courage and temperance are the virtues that deal most with our natural dispositions, suggests that our human nature is constituted in part by our nonrational part. Indeed, this is confirmed by Aristotle's claim at the end of Book 3, chapter 1 that nonrational feelings belong to humans as much as rational calculation and that actions that result from spirit and appetite are human (1111b2-4).

\subsection{Animal and divine natures}

We have just seen that Aristotle thinks that human nature is a complex of rational and nonrational parts. What I want to consider now is Aristotle's view that humans do not only have a human nature. Instead, Aristotle's view is that we also have an animal nature and a divine nature, both of which are contrasted with our human nature. ${ }^{53}$ My main concern here will be divine nature, but we can begin with what Aristotle says about our animal nature.

\footnotetext{
52 Though not exclusively these, as we saw with the Politics example, which concerns a sort of emotional pain rather than bodily.

${ }^{53}$ See Colaner for a discussion of these three natures. Following Whiting 1986, 88-89, I take it that Aristotle employs a broad and a narrow sense of human nature. The former includes the divine nature (and, perhaps our animal nature), whereas the narrow sense is something like 'merely human', which comes out most clearly in contrast to the divine element in us. I suggest that in 3.1 Aristotle is employing this narrow sense of 'human nature'. This contention is corroborated by how Aristotle characterizes human nature in the rest of book 3, which I discuss in
} 
In the course of his discussion on temperance, Aristotle claims that intemperance involves the sensations that we have not in virtue of being human, but in virtue of being animal

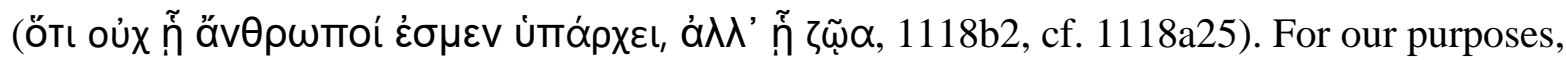
what is significant about this passage is that it indicates that we can think of ourselves insofar as we are humans or insofar as we are animals. Unlike the temperate person, whose appetites are in line with human nature, the intemperate person's appetites are bestial (1118b4). Thus, Aristotle thinks that just as we have certain appetites due to our human nature, we are disposed to have certain appetites due to our animal nature. However, we must overcome our animal nature, to the point where we find such pleasures disagreeable (1119a12). ${ }^{54}$

In a similar way, at the end of the $N E$ Aristotle infamously contrasts our human nature with our divine nature. Arguing for the superiority of the contemplative life, he writes that we are capable of it not in virtue of being human, but in virtue of have something divine in ourselves

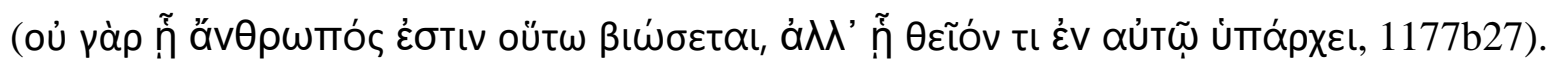
Thus, for Aristotle, we can think of ourselves as (merely) human or as having a divine element in ourselves. And he makes it unambiguous that we should think of ourselves as having this divine nature. He claims that the divine element in us and its activity is superior to our human nature

the previous section. Cf. Keyt, 18 and Segev 2017, 185-6. Scott 240-41 refers to Aristotle's view as 'bifocal anthropology,' which is correct if we exclude the animal nature that is built into us.

${ }^{54}$ Keyt, 18-20 seems to think that we can move beyond our animal nature and presumably most of us do (Cf. Lear 1988, 163). Everson 1990, fn 26 suggests that it is possible for our animal nature to be overstrained (e.g., if one were deprived of sleep or water) in a way parallel to our human nature being overstrained, which suggests that our animal nature is always present in us. My view is that it is always present but so long as someone identifies with their higher nature(s), they can overcome animal nature, even if it is overstrained. 
and its activity. ${ }^{55}$ Moreover, he exhorts us not to listen to the proverbs that tell us to think human thoughts, but that we 'go to all lengths to live a life in accord with our supreme element; for however much this element may lack in bulk, by much more it surpasses everything in power and value' (1177b32-1178a1).

In the next few lines Aristotle goes further, claiming that a person is their divine element and their understanding because we are identified with our best and controlling element (1178a3 - 8, cf. 1168b34-1169a1). ${ }^{56}$ This claim is remarkable but it is also puzzling. If, as Aristotle claims here, we are identified with our divine element, why does he have to exhort us to live in accord with it? After all, you do not have to be exhorted to live in accord with what you are identical to. ${ }^{57}$ The answer must be that Aristotle does not think that we all recognize this identification. So, he must think that we are objectively identified with our divine element, even if subjectively, we do not necessarily identify ourselves with that element. ${ }^{58}$ Indeed, given that Aristotle seems to think that at best most people subjectively identify with their human nature, it

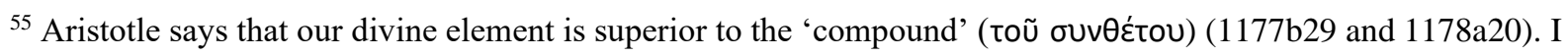
take this to refer to our (merely) human nature, given that the contrast throughout this section is between the divine and the human. Cf. Reeve, 346.

${ }^{56}$ Aristotle almost immediately seems to qualify this claim, writing that the human being (äv $\theta \rho \omega \pi 0 \varsigma$ ) is most their understanding (1178a8). Nothing in my discussion rides on whether Aristotle endorses the qualified or unqualified claim. For discussion, see Charles and Scott and cf. Jirsa 221.

${ }^{57}$ Colaner interprets the three natures — animal, human, and divine — as exclusive. That is, on his view a given human has only an animal nature, human nature, or divine nature.

${ }^{58}$ Cf. Lear 1988, 311.
} 
is safe to conclude that he thinks very few people ever identify themselves with their divine element. $^{59}$

This point is especially important for our purposes. It suggests that we are capable of -at least to some degree — transcending our (merely) human nature, just as we can transcend our animal nature. Again, the exhortation would not make sense if Aristotle denied it was possible.

To see this, consider that in the course of his discussion of temperance, Aristotle writes that someone who lacks understanding (ávóntos) has an insatiable desire for pleasure coming from any and all sources (1119b7). As is borne out in his analysis, we can train and control our bodily appetites, becoming temperate. But this also suggests the possibility that if we were to identify with our understanding, we could move beyond the bodily. As we have seen above, our human nature concerns feelings and the bodily, which is why human virtues are inseparable from feelings (1178a20). But by taking seriously what Aristotle writes about identifying with our understanding, we can see how we could move beyond concern for the human and the bodily. He tells us that our understanding seems to be the natural ruler in us (1177a15) and that decent the person obeys understanding (1169a18). So, by identifying ourselves with our understanding, we would not merely obey its edicts, but they would, in fact, be our own. That is, we would not need reason to rule over our appetites and fears; we would be our reason, if only for a limited time.

Returning to situations that overstrain human nature, based on what we have just seen, Aristotle would think it is possible for someone subjectively (and objectively) identified with their understanding to act well, even when their human nature was overstrained. As we have seen, they would be identified with the ruler of the bodily, rather than merely obeying this ruler.

\footnotetext{
${ }^{59}$ And it seems clear that he does not think that even those who do sometimes identify with their divine element are capable of doing so indefinitely and continuously (1178b35).
} 
And because they identify with their divine nature, they would not be overstrained when human nature is overstrained by natural fears, pains, or appetites. ${ }^{60}$ As a result, they would be free to follow the prescriptions of reason, even in the most extreme situations.

It may be objected that identifying with reason would have precisely the opposite effect. A longstanding debate among scholars is whether what Aristotle says in Book 10 is compatible with the earlier nine books of the $N E$. According to some scholars, the life of theoretical reason Aristotle endorses in Book 10 is incompatible with the life of practical virtue endorsed earlier. Indeed, some interpreters have raised the possibility that the contemplative life could lead one to ignore human virtue, if not to act contrary to it, in order, for instance, to secure for oneself more leisure time to theorize. ${ }^{61}$ On this sort of view, then, someone who identified with their understanding would be the least likely person to endure torture, doing what they should not do in such a situation to get back to philosophy.

I do not want to wade into this debate. ${ }^{62}$ But in response to this sort of objection, I will just point to Aristotle's explicit statements that undermine it. ${ }^{63}$ As we saw above, at 1169a18, Aristotle writes that the decent person obeys their understanding. In this same line he also writes

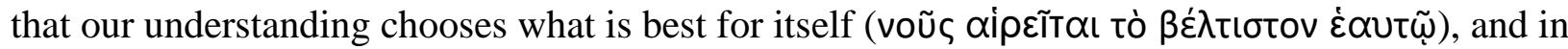

\footnotetext{
${ }^{60}$ Just as a courageous person would not be overcome by the fear of being overmatched, although a professional soldier would.

${ }^{61}$ See, for instance, Kraut 1989, 22 and Lear 1988, 315.

${ }^{62}$ Or related discussion of how to fit together Aristotle's comments about happiness in $N E 10.7-8$ and his view throughout the earlier books of the treatise.

${ }^{63}$ For further arguments that bridge the gap between the practical and theoretical in the $N E$, see Rorty, Roochnik, Wood, and Jirsa.
} 
obeying their understanding, a person does what is right (“ั $\delta \varepsilon \tilde{\imath})$. Thus, what is right is what is best for our understanding, which means that understanding would not prescribe us to do what

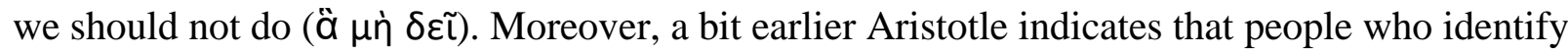
with their most controlling part, that is, their divine part (cf. 1178a3), are most eager to perform just and temperate actions (1168b24-33). A few lines later he claims that people who identify with their understanding are the people who are most eager to do fine things (1169a7). ${ }^{64}$ And just after this Aristotle writes about self-sacrifice, dying for others, and giving up honors and offices - all actions that might be required in situations that overstrain human nature - for what is fine, which Aristotle identifies as the end of virtuous action. ${ }^{65}$ Thus, this objection is overwhelmed by a rather surprising amount of direct textual evidence. Further, this evidence bolsters my contention that a person who identifies with their understanding, their divine nature, would be capable of acting well in at least some situations that overstrain human nature. ${ }^{66}$

\section{Conclusion}

To sum up, there are many previously-open questions about the overstraining passage, leaving us with an incomplete picture of Aristotle's account of voluntariness. Through an analysis of this passage, I have offered a comprehensive account of Aristotle's view of overstraining cases. Put

\footnotetext{
${ }^{64}$ Interestingly, Aristotle also writes that our voluntary actions seem above all to be those involving reason (1169a2). This passage seems like an intentional invocation of Book 3 chapter 1, and at the very least betrays a connection between these issues in Aristotle's mind.

${ }^{65}$ For a thorough discussion, see Wood 2011.

${ }^{66}$ Perhaps not everyone who so identifies, though. At $1141 \mathrm{~b} 3$ Aristotle mentions Anaxagoras and Thales as people who are thought to be theoretically wise but not practically wise.
} 
conservatively, I have argued that in at least some overstraining cases Aristotle thinks that the agent voluntarily does something wrong and that there is a right action available to them. Even put in a modest way, these findings have serious implications for Aristotle's view of ethics.

As we have seen — and as any student of Aristotle would acknowledge — on his view, human nature plays a fundamental role in determining human virtue. Indeed, I have argued that this is why we cannot be compelled to do something utterly immoral and antithetical to human nature. Yet, based on the above analysis, Aristotle would deny that human nature sets the upper limits for ethics. After all, the fact that human nature cannot resist yielding to a situation does not mean that there is not an action that should be performed. Accordingly, Aristotle's ethical view is more complicated than previously recognized. And while human nature may set the lower limits for ethics, we can see that the upper limits of ethics extend beyond human nature.

Although much more remains to be said, this finding alone is significant. And it is not the only finding from the above analysis. For, as I have also argued, Aristotle does seem to think that it is possible for a rare agent to act well in at least some cases when human nature is overstrained. This is possible, I have argued, if the agent identifies not with her human nature but with her divine nature. As with the foregoing, this finding has significant implications for our understanding of Aristotle's ethics. In particular, if this is correct then it draws nearer the political and contemplative lives. Moreover, although there are many details that need to be worked out, it seems that Aristotle believes that it is not only practical philosophy but also theoretical philosophy that can make us ethically better. ${ }^{67}$

\footnotetext{
${ }^{67}$ My thanks to Dan Devereux, Matt Duncan, Jennifer Reed, and to the participants in a session at the 2017 meeting of the Society for Ancient Greek Philosophy for valuable discussion on these ideas. Thanks also to two referees Journal of the History of Philosophy for their helpful comments.
} 
Works cited

Broadie, Sarah. 1991. Ethics with Aristotle, Oxford University Press.

Charles, David, 1999. 'Aristotle on Well-Being and Intellectual Contemplation', Proceedings of the Aristotelian Society, Supplementary Volumes 73, 205-223.

Colaner, Nathan. 2012. 'Aristotle on Human Lives and Human Natures', History of Philosophy Quarterly 29, 211-226.

Cooper, John. 2013. "Aristotelian Responsibility.” Oxford Studies in Ancient Philosophy 45:265-312.

Curzer, Howard. 2005. 'How Good People Do Bad Things: Aristotle on the Misdeeds of the Virtuous' Oxford Studies in Ancient Philosophy 28, 233-256.

Drefcinski, Shane. 1996. 'Aristotle's Fallible Phronimos' Ancient Philosophy 16, 139- 153.

Everson, Stephen. 1990. 'Aristotle's Compatibilism in the Nicomachean Ethics', Ancient Philosophy 10, 81-103

Gottlieb, Paula. 2009. The Virtue of Aristotle's Ethics, Cambridge University Press.

Hursthouse, Rosalind. 1984. 'Acting and Feeling in Character: "Nicomachean Ethics" 3.i' Phronesis 29, 252-266.

Jirsa, Jakub. 2017. 'Divine Activity and Human Life', Rhizomata 5, 210-238.

Kamtekar, Rachana. 2019. 'Aristotle contra Plato on the Voluntariness of Vice: The Argument of Nicomachean Ethics 3.5', Phronesis 64, 57-83.

Irwin, Terrence. 1980. "Reason and Responsibility in Aristotle.” In Essays on Aristotle's Ethics, edited by A. Rorty, University of California Press, 117-55

Irwin, Terrence. 1999. Aristotle's Nicomachean Ethics, Translation and Notes. Hackett. 
Kenny, Anthony. 2011. The Eudemian Ethics, A New Translation, Oxford World's Classics.

Kenny, Anthony. 1979. Aristotle's Theory of the Will. London: Duckworth.

Keyt, David. 1989. 'The Meaning of BIOS in Aristotle's Ethics and Politics', Ancient Philosophy 9, 15-21.

Klimchuk, Dennis. 2002. 'Aristotle on Necessity and Voluntariness', History of Philosophy Quarterly 19, 1-19.

Kraut, Richard. 1989. Aristotle on the Human Good. Princeton University Press.

Lear, Jonathan. 1994. Aristotle: The Desire to Understand. Cambridge University Press.

McConnell, Terrance. 2018. 'Moral Dilemmas', The Stanford Encyclopedia of Philosophy, Edward N. Zalta (ed.) URL=https://plato.stanford.edu/archives/fall2018/entries/moral-dilemmas/

Müller, Josef. 2015. 'Agency and Responsibility in Aristotle's Eudemian Ethics', Phronesis 60, $306-251$.

Nielsen, Karen. 2007. 'Dirtying Aristotle's Hands? Aristotle's Analysis of 'Mixed Acts' in the Nicomachean Ethics III, 1', Phronesis 52, 270-300.

Nussbaum, Martha. 1986. The Fragility of Goodness: Luck and Ethics in Greek Tragedy and Philosophy, Cambridge University Press.

Phillips-Garrett, Carissa. 2017. 'Sungnōmē in Aristotle', Apeiron 50, 311-333.

Reed, Doug. 2017. 'Degrees of Virtue in the Nicomachean Ethics', Ancient Philosophy, 33, 91112

Reeve, C.D.C. 2014. Aristotle's Nicomachean Ethics, Translation and Notes. Hackett.

Roochnik, David. 2009. 'What is Theoria? Nicomachean Ethics 10.7-8', Classical Philology $104,69-82$ 
Rorty, Amélie. 1980. 'The Place of Contemplation in Aristotle's Nicomachean Ethics', In Essays on Aristotle's Ethics, edited by A. Rorty, University of California Press, 377-394.

Sauvé, Susan. 1988. 'Why Involuntary Actions Are Painful', The Southern Journal of Philosophy, 127-158.

Sauvé Meyer, Susan. 2011. Aristotle on Moral Responsibility, Oxford University Press.

Scott, Dominic. 1999. 'Aristotle on Well-Being and Intellectual Contemplation', Proceedings of the Aristotelian Society, Supplementary Volumes 73, 225-242.

Segev, Mor. 2017. 'Aristotle on Nature, Human Nature, and Human Understanding', Rhizomata $5,177-209$.

Stocker, Michael. 1990. Plural and Conflicting Values, Oxford: Clarendon Press.

Taylor, C.C.W. 2006. Aristotle: Nicomachean Ethics Books II-IV, Translation with Commentary, Oxford: Clarendon Press.

Wood, James. 2011. 'Contemplating the Beautiful: The Practical Importance of Theoretical Excellence in Aristotle's Ethics', Journal of the History of Philosophy 49, 391-412.

Whiting, Jennifer. 1986. 'Human Nature and Intellectualism in Aristotle', Archiv für Geschichte der Philosophie 68, 70-95.

Whiting, Jennifer. 1988. 'Comments on Susan Sauvé's 'Why Involuntary Actions Are Painful', The Southern Journal of Philosophy, 159-167. 